
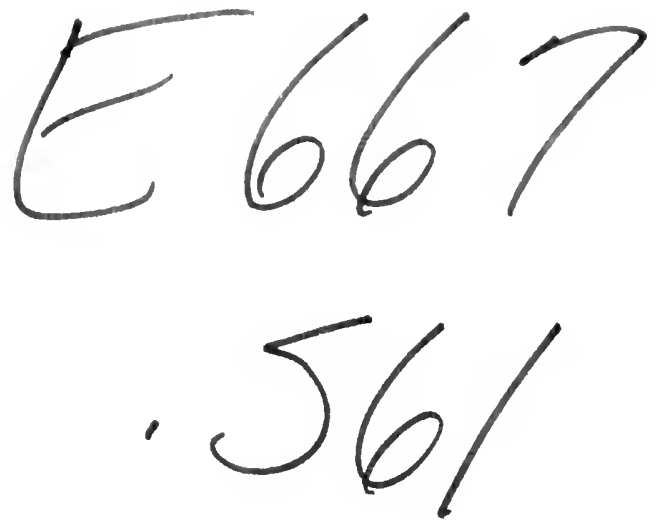

LIBRARY OF CONGRESS

|I || || || || |||||||||||||||||

00020245864 
permalifeo $\mathrm{pH} 8.5$ 


\title{
AIVREW JOHNSON AND THE EARLY PHASES OF THE HOMESTEAD BILL
}

\author{
PRESIDENTIAL ADDRESS READ BEFORE THE MISSIS. \\ SIPPI VALLEY HISTORICAL. ASSOCIATION, AT \\ ST. PAUI., MAY 9, 1918
}

BY

ST. GEORGE L. SIOUSSAT

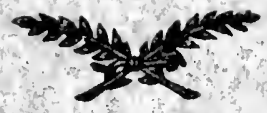

Reprinted from the Mississippi

VALLEY Historical REVIEW

Vol V, No. 3, Dec., 1918 


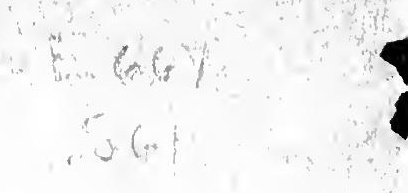


In the Earl of Durham's "Report upon the affairs of British North America," published in the Parliamentary papers for 1839, the problems of public lands and emigration were taken under consideration, and the following judgment, by way of comparison with conditions in Canada, was expressed as to the administration of the public domain of the Uniter States.

"The system of the United States appear's to combine all the chief requisites of the greatest efficiency. It is uniform throughout the vast federation; it is unchangeable save by Congress and never has been materially altered; it renders the acquisition of new land easy, and yet, by means of a price, restricts appropriation to the actual wants of the settler; it is so simple as to be readily understood; it provides for accurate surveys and against needless delays; it gives an instant and secure title; and it admits of no favoritism, but distributes the public property among all classes and persons upon precisely equal terms. That system has promoted an amount of immigration and settlement of which the history of the world affords no other example, and it has produced to the United States a revenue which has averaged about a half-million sterling per annum, and which has amounted in one twelve months to about four million sterling or more than the whole expenditure of the federal government.",

1 This paper was the presilential adress reat at the annual meeting of the Mississippi valley historical association at St. Paul, May 9, 1918.

2 "Reports on the affairs of British North Ameriea from the Earl of Durham, Her Majesty's high eommissioner,' ' in Paliamentary papers, session of 18.39, 17: 74. 
In contrast with the very favorable opinion of the British commissioner may be cited another, which likewise had its origin from without the linits of the United States. In a letter addressed to his brother-in-law, James F. Perry, in March, 1830, Stephen F. Austin, then colonizing Texas under the jurisdiction of the Mexican govermment, wrote as follows:

"We have nothing to fear from this [the Mexican] govt. nor from any other quarter except from the United States of the north. If that govt. shonld get hold of us and introduce its land system, etc., etc., thousands who are now on the move and who have not yet secmred their titles would be totally ruined. The greatest misfortme that could befall Texas at this moment would be a sudden change by which any of the emigrants would be thrown upon the liberality of the Congress of the United States of the North. Theirs would be a most forlorn hope." 3

These strongly opposing comments of the thirties illustrate respectively two points of view of great significance in the history of the public lands of the United States: the point of view of the thickly settled, capitalistic part of the country, and the point of view of the frontier. The clashing of these two points of view goes back to very early times in the history of America, and an molerstanding of the controverted issues is essential to the purpose of this paper.

In the fateful years which brought to a close the exercise of anthority in America by the British govermment there was manifest a rivid contrast between the actualities of American life and the plans of the British ministry. This was true particnlarly of the system of granting lands in those colonies which were under the direct control of the crown. Among the arguments which found the support of government was that which urged the danger of depopulating Great Britain and Ireland through emigration. The fear was expressed that if colonial popnlation in America increased, manufactures would start up in the possessions to the detriment of British interests. On the other hand it was pointed ont that to restrict to the region east of the mounThe passage was cited by Senator Felch of Michigan, Congressional globe, 31 congress, 2 session, ajpendix, $103 \mathrm{ff}$.

3 Stephen F. Austin to James F. Perry, March 28, 18:30, in Austin papers, university of Texas. For his kind permission to use this passage, and for billiographical suggestions, I am indehted to the courtesy of Mr. E. C. Barker.

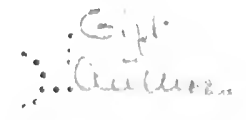


tains the granting of lands, which hat been the policy of the govermment sinee 1763 , might bring ahont in the ast a density of population that would remeler more likely the develepment of colonial matunlatetures, while the opening of the wrest to freese setthement woukl prevent this danger. In Tit, the British govermment put into ceflect a new land polieg which looked towards the definite end of proenring, by a system of survers and sales, an increased revemue from the lamels subjeret to disposition ly the king. That the establishment of the new regulations as to surveys and sales came too late and that the system conld not lore put into eflect was the opinion of many of the roval officials. 'That it was mwise Burke maintaned in his famons speereh on eomeiliattion with America. 'That it was illowal was the theory of Thomas Jefferson, whose "Summary view" contains a somewhat antiquarian but none the less radieal argument as to the limitation of the king's right to detormine at all the conditions of granting land in America. Meanwhile, in direct antithesis to the new royal poliey was the hard fact that alrearly men were swarming over the mountains into the Ohio valley and seating themselves upon the land, with a title if they could get one, withont a title if they conld not.

The contrasts which have been suggested-the opposition between the policy of financial gain and the practical issue of rapid settlement, the effort to control by a system the conflicting interests of different regions, and the mismolerstanding of one region hy another - very shortly reappeared in full intensity both in the new states which had lands to administer and in the public domain which resulted from the cessions of claims of states to the United States; and in the public domain, particularly, these disputes and difficulties continned for many generations. The earlier phases of this development may here be passed over. ${ }^{5}$ Between sections and leaders there developed of

4 The land policy of the British government in its many phases, with the elosely related topies of Indian relations and transmontane settlement, has received exhaustive treatment in the recent work of Clarence IV. Alvorl. The Bississippi rallcy in Rritish politics: a study of the trade, land spcculation, and cxperiments in. imperialism culminating in the American rerolution (Cleveland, 1917). A general reference may likewise be marle to Miss Amelia C. Forl's Colonial precedents of our national land system as it existed in 1800 ([Madison], 1910).

5 Thomas Donaldson, The public domain: its history, with statistics, with references to the national domain, colonization, acquircment of territory. the survey, ad- 
necessity plans of compromise, and, beginning with the period of the thirties, we may notice briefly three policies laid before the American people.

There was, first, the scheme of Henry Clay, - to sell the lands in the west at a price, and to distribute the greater part of the net proceeds from the sales of these lands among all the states of the union. This plan, dear to the whig party and to the eastern manufacturing states in particular, was intimately related in Clay's thought to the desirability of a protective tariff and the undertaking of internal improvements by the federal government. Another plan was that supported by Calhoun, who, abominating both the protective system and internal improvements, wished to lessen also the influence of the federal government through its possession of the land and to this end urged that those parts of the domain which lay within the bounds of organized states should be surrendered to those states. This latter plan was never adopted; but, in combination with other proposals, it made various ghostly appearances long after its most important adrocate had passed from the scene. The third scheme of primary importance and of chief interest to the student of western history, was the one with which the name of Thomas Hart Benton is inseparably connected. In this plan there were several elements. Born in a system presupposed a financial purpose, Benton's plan assume that the lands in the west were to be sold. But it urged, first, that the occupant or "squatter" who had anticipated the legal sale of the land and settled upon it in violation of law, should be protected and should have the first right to buy at the minimum price. Hence the successive preëmption laws. Secondly, it was Benton's idea that the amount of time for which land that had been offered for sale remained unsold constituted a criterion of the quality of the land. He therefore presented and persistently supported a plan for the graduation and reduction of the price of the mosold lands according to which plan lands that had failed for a certain number of years to sell at the minimum price of ministration and several mothods of sale and disposition of the public domain of the United States (Washington, 1884); Shosuke Sato, History of the land question in the Cnited States (.Johns IJophins university Studics in historical and political seicnee, fourth series, vII-IX, Paltimore, 1856); Payson J. Treat, The national land system. 1785-1890 (New York, 1910). 
$\$ 1.25$ per acre should be offered at a less amomnt. 'l'hose not sold at this lower price after another porion of time should be offered anain at a rate still further renherel. Thirdly, Banton urged that the land which would not sell at all - that which he called "rofinse" land - shomld ho given free of elatrige to oceupants."

In another place ${ }^{7}$ I have encleavored to show to what a rreat extent these idrats of Benton wore dreived from the exprerience of 'Tennessee, the state in which Bronton's andier political calleror was cast, the statr which though it hanl trobuically brom in the public domain was hy force of its peculiar history in relation to North Carolina not of it. Here it is munecessary to claborato upon this point: but it may he pointrel out that just as Now Englanders, with Now Fingland idleas, spread thrmselves westward, so both hundreds of people and individual leaders passed ont of Temnessee not only into Missouri, hut into Arkansas, Louisiana and Texas, and carried with them their ways of looking at things. By way of example one may point to the Seviers and Conways of Arkansas, to Sam IIouston of Texas, and to Gwin of Califormia. Moreover, in what we may call the 'Tennessee regime of the democratic party, the cra of Jackson and Polk, the plan of Benton received the support of the national administration." Benton's "log caloin" bill, first brought up in 1824 and expanded in 1826, was unsuceessfully urged for fifteen years, though various stages of preamption were rone through. Both Jackson and Van Buren, however, approved his plan; and the graduation principle was adopted by the execntive in treaties with the Indians where lands were to be sold. ${ }^{10}$ In 1841 , as an

6 Raynor G. Wellington, The political and sectional influence of the public lands, 1898-1842 ([Cambridge], 1914).

ist. George L. Sionssat, "Some phases of Tennessce politics in the Jackson period," in American historieal revicu', 14:51.

8 Lois K. Mathews, The cxpansion of Xew England, the spread of Xou England settlement and institutions to the Mississippi river, 1621)-1565 (130ston, 1909), ehs. $1,6-10$.

9 While Irenry Clay consistently opposed Benton's scheme, it received at different times partial support from Daniel Webster. See Congressional debates, 4: part 1: 660, 666, 674, and Works of Daniel Webster (fifth edition - Boston, 185:3), $4: 391$ fP., $523 \mathrm{ff} ; 5: 356$. It was Iames Madison, Webster sail, who had called his attention to the importance of the publie lands.

10 Charles .. Kapuler, Indian treatics (Washington, 1904); Chickasaw, 19:2, 2: 359; Chickasaw, 1834, 2: 121-422, Chiplewa, 1838, 2: $516-517$. 
onteome of the whig victory in the election of 1840, a hybrid law was passed ${ }^{11}$ which bronght into temporary activity Clay's plan of distribution and into permanent force the preëmption part of Benton's scheme. ${ }^{22}$ By reason of the peculiar relation of this matter to the whig tariff policy, and becanse of the grand fiasco which overtook the whigs on the death of General Harrison, the distribution plan automatically ceased and the efforts to bring it into existence again did not succeed though distribution like Calhom's cession to the states lifted its head at various times thereafter. ${ }^{13}$

For the next two or three years no land measures were enacted comparable to the law of 1841 . But in the second congress of 'Tyler's administration, - the twenty-eighth congress, - which assembled in 1843, there was a democratic house of representatives; and in this congress the plan of graduation and reduction, which in the thirties had been the chief rival of distribution, made its appearance anew. Henceforth, the graduation bill was a hardy annual, until in the session of $1853-1854$ it at last became a law.

At least for the earlier part of the Polk administration this bill was pressed as an administration measure. In the first session of the twenty-eighth congress the hill was introduced in the senate by Robert J. Walker of Mississippi and in the house by Houston of Alabama. At this time there was little debate. In the campaign of 1844 the Texas and Oregon questions, with that of the tariff, over-shadowed all others. When the election was over the bill was vigorously debated in the house of representatives. ${ }^{14}$ After Polk became president he appointed Shields of Illinois commissioner of the land office, a position which fell within the department of the treasury, the head of which, Robert T. Walker, was a prominent supporter of the graduation plan. ${ }^{15}$ When the twenty-ninth congress assembled, Shields in his annual report, Walker in his communication as secretary, and the

11 Approvel September 4, 1841. Tnited States statutes at large, 5: 453.

12 Andrew Jackson, at this time in retirement at the Hermitage, asked his friend F. P. Thlair to thank Benton for the $\log$ eabin bill. Jackson to F. P. Blair, 18t1, 115 Jackson papers, library of congress.

13 George M. Stephenson, Politiral history of the public lands, from 1840 to 1869, from pre-emption to homestead (Boston, 1917), eh. 6.

14 Congressional globe, 28 congress, 2 session, 21, 50-53, 69-72, 82-84, 240, 248.

15 Walker is one of those to whom the authorship of the homestead principle has leen attributed. 
president in his message, 13 all ureed the expediency of putting into foree at once the gratuation of the priese of the publice lands. Introduced in both houses at the breminning of the session the bill

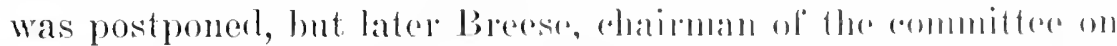
public lands in the semate, and Mo('lermand, who helel a similat position in the house, each pusherl the measure. ${ }^{17}$ The hill passed the senate by a vote that followerl pretty distind ty paty lines: the democrats for the bill and the whigs opposing it." This hill was then sent to the house which han been somewhat sharply dehating a bill of its own. The homso laid aside its own bill aml passed the senate bill with amemiments by a close vote. ${ }^{19}$ The length of the graduation period dirl not suit the house, so it was sent back to the senate with amendments. The senate tinkered with it further and when it went hack to the house the second time it was laid on the table a few days before the close of the session. ${ }^{20}$

An examination of the legislative course of the bill brings out two observations of interest. In the first place, in congress also the bill was claimed as an administration measure. The preceding year, just after the election, McClernand, plearling for the graduation bill, had maintained that the victory of Polk showed that the people demanded the bill. ${ }^{21}$ Now Bowlin of Missouri again made this a direct appeal. It was, he said, one of the great issues in the contest of 1844 and stood in contralistinction to the whig scheme of distribution. The people had decided in favor of graduation, the president had brought it before congress. Referring to Texas, Oregon, the tariff and the independent treasury, he said, "The four fir'st great acts of the political drama have been passed. That Democrat is prepared to make a stumbling block of the fifth?", ${ }_{22}$ This assertion that the bill was distinctly a party test was not unquestioned, ${ }^{23}$ but

16 The statements of each of the three men may he fomm, ibid., 29 congress, 1 session, aplendix: Polk's message, 7 ; Walker's, 12; Shields', $39 \mathrm{ff}$.

1 Congressional globe, 29 congress, 1 session, 45, 56, 953, 967, 958, 1040, 1057 ff. The speech of MeClernand of Ohio, July 10, 1846, is in ibid., 29 congress, 2 session, appendix, 33.

18 Ibid., 29 congress, 1 session, 1073.

19 Ibid., 1075, 1094.

20 Ibid., 1195.

21 Ibid., 28 congress, 2 session, 72.

22 Ibid., 29 eongress, 1 session, 1061-1062.

23 Remarks of Vinton of Ohio, itid., 1076. 
the rotes in both senate and house bear ont the general accuracy of the claim. In the second place, however, there developed an important exception to the support of the democratic side which, together with the absence of many members, appears to have been the canse of the final defeat in the house. This was the opposition of many democrats of the eastern states who joined with the whigs: ${ }^{24}$ an aligmment which had been predicted in the course of the debate. This attitude of the eastern democrats was of course not new; it had been manifest in the controversies of 1838 and 1839. But its reappearance now at the very time of the introduction of the Wilmot proviso is significant. On the other hand it is worthy of note that most of the democrats of the old south, inching the South Carolina contingent, were found ranged with those of the southwest and the northwest, in common support of the bill against the whig opposition. ${ }^{25}$

To follow briefly the course of the graduation bill: in the second session of the twenty-ninth congress Polk, besides recommending graduation in his first message, sent in a special message, ${ }^{26}$ saying that the enactment of the measure would increase the revenue from the public lands, which was needed for the prosecution of the war with Mexico. The graduation bill was again introdncerl, but more significant was the effort of the committee on ways and means to embody the graduation principle in a revenue bill. ${ }^{27}$ In both forms the proposed legislation failed. Besides other disturbing forces, the absorption of interest by the bounty law of $1847^{28}$ which offered warrants for land to the soldiers and officers of the Mexican war, rendered less likely than before the passage of the graduation bill. The effect of the bounty law naturally was to take from the domain hundreds of thousands of acres. A sharp division between east and west appeared in the insistence on the part of the west that the warrant holders should become settlers, and in the objection

24 Remarks of Henley, ibid., 1071.

25 Ifid., 1069, 1073, 1179. In 15:37-18:9, when Van Buren was urging graduation, the hill passed the senate and failed in the house. Then Calhoun and his followers were in olyosition. (Wellington, The politieal and scetional influence of the public lands, 68.73.) Now Cahloun and Benton supported the bill. This makes the more marked the position of the eastern demoerats.



2. Compressional globe, 29 congress, 2 session, 440, $530 \mathrm{ff}$.

24 I'mited states statutes at large, 9: 123; cf. Stephenson, Political history of the mellic lands, from 1840 to $186 \%$, from pre-emption to homestead, ch. 9. 
of castern men that the east should not be dreopmlated in oreler that the west might be settled.": The homnty aret was important not merely for itsolf but herause it initiated the policy of thus granting lands, a policy which was eontinued thromerh the atets of $1850,185^{\circ}$, and 1857 . The cause of the sraduation bill in the thirtieth congress was hopeless, lor the whigs rontrollerl the house of representatives. The ontstanding foature of these years was an able report hy Collamer of Vermont against the graduation policy. ${ }^{30}$ When the thirty-first congress met in 1849, althongh the administration was whig, the democrats reained control of the organization of both houses, and the grarlnation bill appeared again. Bowlin of Missonri was chairman of the committee on public lands in the honse of representatives and Felch of Michigan in charge of the same committee in the senate. In the thirty-second congress, W. P. Hall, a demoerat from Missouri, succeeded Bowlin, while Felch continued. The thirty-third congress once more saw both houses of congress and the executive department under democratic control. Dodge of Iowa was chairman of the senate committee and Disney of Ohio chairman of that of the house. In the first session of this congress the graduation and reduction bill became law.

Like most of the land measures that were proposed, the plan of graduation and reduction was in reality an effort to effect a compromise between the principle of revenue and the interests of the actual settlers. The same statement may be made as to the concession of the right of preëmption, particularly as embodied in the act of $18+1$. Under this law and those which had preceded it, the settler was favored in that he had the right to buy at the lowest government price. The government, however, received a revenue from the land though this revenue was diminished by the difference between the minimum price and that which the land might have brought at anction. The settlers were dissatisfied with the act of 1841 ; they asked for a general prospective preëmption which should apply to the musurveyed public domain as well as to that which had been surveyed, or for an extension of the time for making payments on preëmpted lands. The latter concession, if granted, would have been equivalent to a reestablishment, in part, of the former credit system. ${ }^{31}$

29 Remarks of Perry of Maryland, Congressional globe, a9 eongress, a session, 254.

30 Reports of the house of representatives, 30 coneress, 1 session, no. 732.

31 Stephenson, Politieal history of the public lands, from 18 th to 1868. from pre- 
But the demand had been heard for more than this, for more than a mere compromise. That the government should give land ontright to actual settlers and surrender entirely the seeking of revenue, was no new idea. The head rights of Virginia and other colonies were a precedent of sufficient antiquity, and many gifts had been made by the government of the United States to individuals. $^{32}$ A distinction must be drawn, however, between free gifts of land to actual settlers, either those already seated or prospective occupants, and grants of lands that involved some service rendered in return. This will serve to distinguish the real homestead grant from the many forms of bounties given for military service or some return to the government which might be considered a fair compensation. Thus, as far back as 1840 the settlers in Oregon lad petitioned for donations of land, ${ }^{33}$ and ten years later, after much debate, such grants were made. ${ }^{34}$ In the meantime similar gifts were made to settler's in Florida. ${ }^{35}$ In both these cases it was considered that a special return was rendered to the govermment either because the recipients were holding the ground in so distant a region as Oregon or because they were acting as a defense against the Indians, as in Florida. The multiform grants to the states were likewise justified upon a theory of compensation. ${ }^{36}$ But the homestead plan asked the government to give away the public lands and sacrifice all direct revenue therefrom at a time when the settlement of the west was no longer uncertain. However strong the arguments for homesteads was it was not the advantage to the government that was the most convincing.

Having made this distinction between the homestead idea and the grant for military or other service, I wish to attempt a simemption to homestcad, 97-103. Cf. many petitions to congress in House of representatives papers (manuseripts), in library of congress, packages marked "Wisconsin public lanis,' 1843-1847, 1845-1848.

32 Foril, Colonial preeedents of our national land system as it existed in 1800, ch. 6 ; Treat, The national land system, 1785-1820, ch. 12.

33 Senate doeuments, 26 congress, 1 session, 514; Congressional globe, 26 congress, 1 session, 60, 103, 296 .

34 Art approved September 27, 1850. Cnited States statutes at large, 9:496 ff.

3. Act of August 4, 1842. Ibid., 5: 502.

36 Matthias N. Orfieh, Federal land grants to the states with speeial reference to Minnesota (Minneapolis, 1915). See also Treat, The national land system, 17851820 , ch. 11. 
ilar delimitation between the strict homesteat of grood land and Benton's idlea, which persisted throughout the following periorl, of giving to actual settlers either directly or through the states the "refuse" land. "This was one part of the "log cabin" bill. The idea, no doubt, found a speralal development in temessee where ocempants or squatter's harl sottled upon poor lands or odel bits of land not eovered by North Carolina warrants. In the Perleral land system Benton wished to make provision for those mable to buy at the land sales even after the priece had been grantnated and reduced. As to Temnessee the irlea was pressed in rongress by David Crockett, in opposition to the rest of the Trennesser telegation, who asked permission to sell refuse lanrk in 'Temnessee for the benefit of schools. Finally these lands were given to Tennessee. ${ }^{37}$

A somewhat different phenomenon appearel in another sonthwestern state. In his Biographical and pictorial history of Arkansas, Hallum ${ }^{38}$ claims that the origin of the lomestead policy goes back to Governor E. N. Conway of Arkansas, at one time federal auditor. It appears that but few soldier's settled on the lands granted to them in Arkansas and these lands were sold by the state for nompayment of taxes. The burden of the back taxes was sometimes so large that no one would buy the lands, and they remained on the hands of the state. In 1840 Conway recommended that "a law be passed donating to every individnal who would settle upon and improve a quarter section of such land, the right of the state thereto, conditioned that the taxes afterwards aceruing upon the land thus occupied should be regularly paid, or the land and improvements thereon shonld revert to the state and remain sul).ject to private sale." "Were such a law passed," he continued, "and the lands thus donated, whilst held under such titles only, exempted from axeention of sale for any other debts than state and county taxes, it is the humble opinion of the auditor that the military distriet would in a few years be greatly improved and the revenue angmented. Persons not wishing to avail themselves of the benefits of such a law should he allowed as they now are, to purchase at private sales, lands which had once been offered at public 3 r Ibid., 353.

38 John Hallum, Biographical and pictorial history of Alkansas (Allany, 1987), 55. 
anction by the anditor and remained unused and not donated." 39

Two years later Conway reported to the assembly that many persons had arailed themselves of the benefits of the law ${ }^{40}$ passed by the last legislature, so that "some of these wild lands heretofore uninhabited, meultivated and producing no revenue have become changed to the home of industrious and enterprising persons who settled, improved, and will cultivate them."

With due local pride Hallum says that Conway's recommendation was copied by the press of every state in the union and commendatory letters were received by him from many persons of anthority. He conchudes that Andrew Johnson, "the greatest of national humbugs," appropriated the idea. In deferring judgment on this opinion we may recall that Conway, like Benton, was a representative of the westward emigration from Tennessee.

But the most impressive example of a liberal land policy was brought to the attention of the frontiersmen of the United States through the settlement of Texas across the southwestern border. The impresario Stephen F. Austin gave especial care to the establishment of a land system. His original proposals to the Spanish governor of Texas looked to grants of a moderate size, but the colonization law of Jamuary 4, 1823, under which, on February 18 of the same year, the Emperor Iturbide approved Anstin's petition to settle three hundred families, vastly augmented the grants to be made to settlers. Austin was empowered to grant headrights of a leagne $(4,428$ acres $)$ of

39 State of Arkansas, House journal, 1840, p. 27.

40 Ibid., 1842, appendix, 20. The act is in Laus of Arkansas, 1840, 60 ff. From a memorial of the state of Arkansas to congress, apriroved December 16, 1838, may be cited the following passage, which excellently illustrates the western point of view. The assembly was urging the passage of a general preëmption law. "The pioneer of the western wilds is not a lawless intruder, who settles upon the lands of the govermment with the unrighteous design of robling the publie and obtaining by trespass a claim against the government. $H_{e}$ is in truth the greatest benefactor of the public. Had it not been for his adventurous and daring spirit, had no man ever settled ujon the publie lands until he had purehased it, eivilization would not at this day lave reached the Mississiypi, and the fairest part of our land would still remain an unsettled willerness. The wealthy, those who have the means to purchase their thonsancis of acres of the government, those who have the eapital to interest in labor, and the means to open extensive farms and plantations, are not the men to penetrate the wilderness. The pioneer must first, with his axe and rifle, open the path. The comtry must lie somewhat settled before there arises any demand for the public lands." 


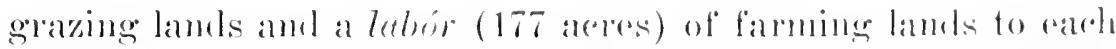
head of a family; while impresarios who borought in seftlers

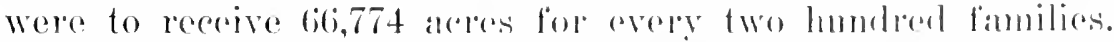
With the severest exortion Anstin managerl to rotaln his privileges through the muertain eomsen of Mexidan polities. Within

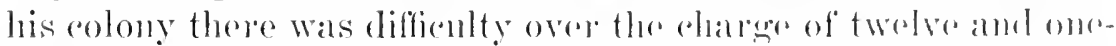
hall cents an acre which Anstin insistod on writing into his contracts, though lis grant from the sorromment mank no roference to sucla payments. This small foe Anstin folt to be neceessary and just, because otherwise he wonld reecive nothing to cover the cost of the eareful surveys and records which he marle, together with his reguirement of the proof of the goorl ahitrater. of intending settlers, essential parts of his plan of colonization.

With the military phases which of neessity marked tho Texals revolution, the plan of bounties which had been so prominent a feature in the United States made its appearance. By the ronstitution adopted in 1836, all persons living in the republic at the time of the declaration of independence were to be considered citizens, and anyone who had not received his portion of land conld claim, if a head of a family, a leagne and a labir, or if a single man, one-third of a league. By legislation the hearlright system was extended to later volunteers in the revolntion. In 1837 a land office was established with a series of minute regulations. Various "prices" were attached to the fulfillment of these grants, but as these ran from one dollar and fifty ents to seven dollars for a labor of 177 acres, it is evident that the land was practically given away. In 1839 immigrants were offered smaller amounts, 640 acres to hearls of families, and half that to single men, conditioned on three years of residence. Later there was superadiled the requirement that ten aeres of land must be eultivated, and the locations surveyed aml marked. Such were the opportmities to acquire lands in Texas in the forties. ${ }^{41}$

41 For the development of the land system of Texas see D. C. Wonten. Compre. hensive history of Texas, 1685-1897 (Dallas, 1898), 1: 784-849; and for the earlier period - that of Austin's management - two papers ly Fugene C. Barker, "The government of Austin's colony, 18:1-1S31," in Southucostern historion quartroly.

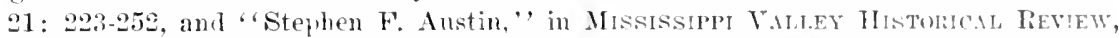
5: 20-35. The laws may he studied in Lau's of Texus. 18?.0-1945, edited ly Hans P. N. Gammell (Anstin, 1898-1904); .Tohn and Henry Sayles, Early laws of Texas (St. Lonis, 1888); and dames W. Dallam, A digest of the laws of Teras, coutaining 
It may fairly be claimed, then, that western experience and traditions made entirely intelligible the request that land be given to the actual settler without the demand of a price, and that there would be no difficult transition from Benton's proposed gift of poor land to that which promised to the settler the best land, however much opposed to the revenue policy the latter might be. Thus there was a distinctly western origin or approach to the homestead bill. But, while this might easily have commanded the rotes of all the senator's and representatives of those states which still retained the characteristics of the frontier, or whose ties with the frontier remained particularly close, it would never have succeeded in overcoming the financial hostility both of the eastern states and of those states originally western that through denser settlement and the occupation of all their good lands were likely to become more and more disposed toward the eastern point of view. As to the western origin of the homestead legislation, one finds, as might be expected, that this measure had its begimning in association with the bill for graduating and reducing the price of the public lands and that this association was a necessary one. But it remains to be seen how men of the east who consistently opposed graduation and reduction came over, at least on the part of considerable groups, to the active support of the homestead bill.

In the spring of 1844 a group of individuals who described themselves as the central committee of the "National reform association" addressed a letter to James K. Polk, as a "candidate for public office" to solicit an expression of his views on a subject which, they thonght, vitally affected the rights and interests of their constiments. They proceeded to say,

"We see this singular condition of affairs: that, while wealth in our country is rapidly accumulating; while internal improvements of every description are fast increasing, and while machinery has multiplied the power of production to an immense extent; yet, with all these national advantages, the compensation for useful labor is getting less and less. We seek the cause of this anomaly, and we trace it to the monopoly of the land, which places labor at the mercy of capital. We therefore desire to abolish the monopoly, not by interfering with the conventional a full and complete compilation of the land laus together with the opinions of the supreme court from 1840 to 1844 inclusice (Austin, 1904). 
rights of persons now in possession of the land, but hy arresting the further sale of all lands not yot apporopriatal as privato property, and hy allowing these lands levealter to he liecly occupied by those who may rhoose to settle on them. Wre plopose that the Public Iands hreafter shall not be onned, hut oceupied only, the ocempant having the right to soll or otherwise dispose of improvements to any one not in possession of ofluer land; so that, by preventing an! inclividual foom hecoming possessed of more than a limited quantity, every one may enjoy the right.

"This measure, we think, would gradually estahlish an orpuilibrim between the agricultural and ofher useful occupations, that would insure to all full employment and fair rompensation for their labor, on the lauds now held as private property; and to each individual on the public lands the right to work for himself on his premises, or for another, at his option." 42

In the brief endorsement_- "not worthy of an answer" which Polk made upon this document, one senses immediately his feeling that this was a radicalism not to be encouraged. But to students of economic history the development of the labor movement in the United States and the radical doctrines of the land reformers of the eastern states have formed an inviting field for investigation. As this field has been thoronghly exploited by Mr. John R. Commons and his associates, both in the Documentary history of Amprican industrial society and rery recently in the History of labour in the L nited. States, we need here only with great brevity recall the increasing activity, in the midst of a sharply pressing conflict of wages and prives, of the labor movement of the second quarter of the ninetrenth century, and the influence, in the propagation of a loctrine of land reform, ${ }^{43}$ of such men, largely of English and Trish extrac-

42 Polk papers, library of congress, vol. 56. The letter, dated at New York, April 20, 184t, was signed hy eight persons, among whom were George Il. Exams and Lewis Masquerier.

43 The earlier agrarian movement is disenssed lw Miss Helen L. Sumner in John R. Commons and associates, History of labour in the I'nited States (New York. 1918), 1: $234 \mathrm{ff}$. There was also a land reform group of German origin, of whom the leading spirit was IIerman Kriege. Itenry E. IIoaglanł, ibid., 1: 5.44-535. See also Documcntary history of American industrial sorit ty, edited ly .John li. Commons and assoeiates (Clereland, 1910-1911), $7: 310-312$, for doeuments illustrating the attitude of the German group in $18+5$. 
tion, as Thomas Skidmore, Thomas Spence, George Henry Evans, and Thomas Ainge Devyr.

When to the feeble presses started by these radicals of the east there was added as the medium of a convert the great newspaper of Horace Greeley, the cause of land reform was much advanced. The decade of the forties was a decade of "isms," of which Horace Greeley was the prophet. As Mr. Commons pointedly expresses it, "He was the Tribune of the people, the spokesman of their discontent, the champion of their nostrums. He drew the line only at spirit rappings and free love." ${ }_{44}$

Upon Greeley's mind, as upon a sensitive receptive apparatus, there played idealistic influences from two distinct sources. The one, which we may call applied transcendentalism, came from Massachusetts, and now endeavored to realize itself in such experiments as Brook Farm, in 1842. After the next year, the representatives of this group identified themselves with the interest of the working people, and about the same time, took up Brisbane's Americanization of the social philosophy of Fourier, and proceeded to the organization of phalanxes with an enthusiasm wortly of a more successful cause. ${ }^{45}$ The other current which influenced Greeley came from the workingmen. Thomas Spence, an Englisl net-maker, wrote a book advocating that "all the land of England shonld be leased and the proceeds divided equally among all the people of England.', Spence's ideas exerted some influence upon the first workingmen's party of New York. But the man who more completely interested the working classes in the land question was another Englishman by the name of George Henry Evans, who came to America in time to undergo apprenticeship as a printer, and who, in 1829, began the Working Man's Advocate. Evans was a philosopher who believed in the "natural right of all men to land, just as to sunlight, air and water." As a landless class, the workingmen of the east were slaves to a master class which owned their means of livelihood. I and reform, he urged, must precede the aholition of negro slavery.

41 Jid., 7: introluction, 20. This introluction is a reprint of Mr. Commons article, "Ilorace Greeley and the working elass origins of the republiean party," in Politim swine quarterly, 24: no. 3. Examples of (ireeley's editorials are given in Documentary history of Ameriran industrial socicty (Commons and associates ed.), $8: 40-44$.

4.5 Ibid., 7 : introduction, 26-28. 
Evans differed from the communists in his emphasis upon the individual right to the soil. The panie of ls:3i gatro a temporary setback to the labor moventent. Whan more onsonraging times appeared, Evans resurrecend his paper muler the name of Young Americe and organized a party known as the national reformers. To this propaganda belongs the colebraterl pamphlet "Vote yourself a lam," which, with many other vory interesting documents bearing on this period, Mr. Commons has reprinted in the Documentary history of American industrial sociely. ${ }^{46}$ Botween $184 t$ and $18+8$ the agitation of the land reformers made great strides, assisted by the attention which the anti-rent riots in New York state called to this particular issur. ${ }^{47}$

The work was angressively pushed by the "industrial con-

46 Ibid., 7: introduction, 29-33. Sce also ibid., 7: 25s ff, for important docllments. Some aceount of Evans is given by IIoagland in Commons am associates, History of labour in the United States, $1: 520 \mathrm{ff}$.

47 Besides the work of Mr. Commons and his assoriates there may lie eonsulted also the older book of Rudolf E. Meyer, Heimstäten- und andere Wirtsehaftsgesetze der Tereinigten Staten von Amerika, ron Canada, Russland, China, Indien, Ru. mänien, Serbien und England (Berlin, 1853); aml Stephenson, Political history of the public lands, from 1840 to 1869. from pre-emption to homestead, 103-113. The ran Buren manuscripts in the library of eongress contain many important letters, espeeially in relation to the eampaign of 1848; see fartieularly Van Buren's reply. to the Buffalo eonvention, 56 Van Buren manuseripts.

In connection with this subject, some interest attaehes to a group of letters which, several years later, Andrew Johnson received from Thomas Ainge Devyr, one of the most prominent of the land reformers. Devyr wrote from Williamshurg, New York, on December 9, 1859, giving Johnson a sketch of the history of the "land reformers" organized in New York in 1844. These were nearly all demoerats. Deryr latd condueter a democratie paper at Williamsburg at the time. The demoeratic party proved hostile; the Greeley whigs made a show of faroring land reform, and so dird the Buffalo platform men. Those imposters, wrote Deryr", "stole our thunder" in 1849, and took nineteen-twentieths of those levoted to the cause. "Ours" was the free soil party up to that time. Now (1859). Devyr urged the demorrats to take the matter up again. Devyr added an interesting account of his own history; twentr. three years before, he had published in the north of Ireland a pamjhlet reprinter here, and in the chartist movement he had "narrowly" eseaped to the United Staltes, in 1St0. Upon the lack of the letter eited Andrew Jolnson wrote "Not reasl as yet." On .Jamary 1, 1860, Devyr wrote again, sonding a printed cireular. A thiri letter followed January 8, in whieh the writer interestingly eonnects the homesteat agitation with the anti-rent diflieulies in New York. Devyr wrote a fourth time January 21, addressing Johnson as "general-in-chief" of the cause, amd salying that he was unwilling to aserilie the neglect of his lettors to deliberate intention. Johnson-Patterson manuseripts in the jossession of Mr. A. .l. Patterson, of Crreenville, Tennessee, to whom aeknowledgment is marle for the permission to consult these papers. Some account of Dery is given by Hoaglint in Commons and assoeiates. History of labour in the United States, 1:532. 
gress," of which the sessions, beginning in 1845 , were held each year. ${ }^{48}$ But the most widely heard voice continued to be that of Greeley.

It is hardly necessary to point out the great difference between these ideas and those of Benton. If logically carried out the principles of Evans justified the taking of land from monopolists in any part of the world. It was only America's fortunate possession of a public domain that offered the opportunity to press the demand for room for the landless in the yet unsettled region of the west rather than in the crowded east. But it is not hard to see how this eastern appeal could be made to apply to the west, could spread to the western states and territories and would result in the petitions, which, with thousands of names attached, were submitted to the congress of the United States. But for congress successfully to be persuaded necessitated the aggressive activity of men in that body, as well as the exhortations of those outside. Within congress the cause of the homestead was taken up and steadily pressed by Andrew Johnson of Temessee, to whose preparation for leadership in this regard some attention must now be given.

The years which Andrew Johnson had lived before his entrance into the house of representatives in 1843 had already gone to make up the strong but somewhat unconth personality of the man. ${ }^{49}$ Born in 1808 in Raleigh, North Carolina, at fourteen years of age he was "bound out" to learn the trade of a tailor; and a couple of years later together with an elder brother William he was advertised as a rumawa from his master. After another two years he with his brother and stepfather had tramped across the momtains to the upper valley of the Tennessee, where in the long depression between the Alleghany mountains and the Cumberland plateau, which extends to the northeast far up into Virginia, lies the little town of Greenville. Among the treasures of the Drexel Institute in Philadelphia, the curious visitor may see two old account books much worn

48 Hoagland treats of the industrial congress in ibid., 1: 547-551. See also the masses of petitions in the House of representatives manuseripts, lilurary of congress, which show the westward movement through Ohio, Illinois, and Wisconsin, and the influence of the lami reformers and the industrial congress.

49 An extended sketah of Andrew Johnson, from a not over-friendly point of view, is found in Oliver 1'. Temple, Notable men of Temnessee, from 1833 to 18\%5, their times and their contemporaries (New York, 1912). 
and battered which were kept hy Johnson in connection with his tailor shop. They show him lemeling small smms of money, and later performing small commissions on his trips to Washington. Unfortmately neither these nor any other soureses have anything to say abont the intellectual life of the yomng tailor. From later materials, however, one gathers that there was an early development of his oratorical ability, amel that he was much given to reading, an art which had heren painfully acquired. One hears nothing of feats of strength like those which grave a local celebrity to Lineoln, in whose arly career there are incleal many elements of similarity. Nor, in Johnson's case does the seriousness of life seem to have been relieved by the hmmour which even though lude and rough, resened Lineoln from the melancholy that sometimes overtook him. The earnestness with which Johnson felt obliged to defend himself against charges of infidelity permits one to suspect that he had perhaps been characterized by that skepticism of a cruder type which one meets in so many cases in the early part of the nineteenth century. ${ }^{50}$ At a later time he showed that he had a considerable acquaintance with English literature and that if the range of his knowledge was limited, his mastery of what he had was thorongh.

But his mental activity seems to have foumd its natural ontlet in the field of polities. In this fiell one principle was undoubtedly a guiding force thronghout his whole carecr. This was a bitter dislike of the superiority clamed by some men or for some men by virtue of greater possessions of wealth or more fortunate eiremmstances of birth. The vehemener with which he expressed these views surprises one, for one could hardly imagine the quiet town of Creenville or the whole valley of East Temnessee to be the theatre of a class struggle whether on the basis of hirth or wealth. Here, with comparatively few slaves, there was none of the manorial life that, existing in much dignity and culture in both oldes and newer regions of the south, has so often and so mistakenly been regarded as universal. On the contrary, East Tennessee was a region of small farms in an upland valley. It was not a trpical "poor" white" region. One feels, therefore, that Johnson's hostility to aristoeracy must represent resentment at

so See the printed pamphlet, Letter of Androw Johnson to his constituents (Washington, 1845), to which reference is marle below. 
the treatment of social inferiority accorded to the poor artisan by the well-to-do farmers, and also an element peculiar to Johnson's own personality.

Within ten year's from the time that Johnson reached Tennessee he had succeeded in polities to the extent of securing election, first to town offices in Greenville, and then as representative in the state legislature. In 1834 Tennessee adopted a new constitution. Before the convention came many questions of change, such as the demand for an abolition of slavery put forth by persons in East Tennessee. The sectionalism of the state was strongly marked, as it is to this day, finding a natural basis in the division of the state by the Cumberland plateau and the Tennessee river. When Johnson entered the lower house of the Temessee assembly, it was at the first session after the adoption of the new constitution, when many statutes of semiconstitutional nature were debated so that there was an umusually good opportunity for a new representative to be educated in the practical working of the state government. It was the very time also of the revolt against the domination of state politics by the friends of General Jackson, ont of which, so far as Temnessee was concerned, developed the whig party. After a period of hesitation Andrew Johnson threw himself whole-heartedly into the service of the regular democratic organization, a course which he tenacionsly pursued to the time of the civil war.

Defeated for the next assembly, becanse, it is said, of opposition to internal improvements, Johnson was more successful in 1839. After another term in the honse and one in the senate of the assembly, he was elected in 1843 representative in congress of the first Tennessee district. But before an attempt is made to follow him in his congressional career it will be best briefly to consider the work which he had done and the estimate which harl been placed upon him when he entered national politics. Alrearly he had exhibited political ability and force to an extent that warranted James K. Polk, chief master of the democratic organization in Tennessee, in suggesting Johnson as a possibility for the senate of the United States. ${ }^{51}$ A bitter partisan, Johnson shared in the maneuver by which the democrats kept

51 James K. Polk to Maclin, Janury 17, 1812. Polk papers, library of congriess. 
the state a couple of years without any Uniterl States senators rather than elect a whig. Ilis radical fendencies had alroady manifested themselves in his support of the proposal to form East 'Temmessee into a separate state, a reflection of sectional jealousy. But the activity which later was most used abainst him was his support of the "white basis" for the arrangenent of the congressional distriets in 'Temnessee. This plan looked to the substitution in the arrangement of these districts of an apportionment according to the white population alone, in place of the existing "federal" basis, by which five negro slaves were to eount as three white men. 'The effect of the change would be to give East Temnessee, with its fewer slaves, a larger share of the representatives in congress. It is interesting to examine Johnson's defense of this policy in answer to the charge of sympathy with the abolitionists which very naturally his cnemies raised against him. He said that it was necessary to make the change for the very purpose of defending slavery. If the nonslaveholders of East Temnessee were satisfied within the state it would be the best means of preventing antislavery tendencies and making the state united. Against slaveholders as a superior class he frequently expressed himself in vigorous terms. But so far as I know his speeches and private letter's reveal little or no sympatly with anything like abolition and his dislike of the abolitionists in general and of the New England sort in particular appears to have been thorough.

Such was Andrew Johnson when he entered congress in December, 1843, in the same session in which Stephen A. Douglas and Howell Cobb also began their congressional service. But whereas Douglas was at once placed at the head of a select committee to investigate a matter of apportionment, and thus brought into a conspicuous position, Johnson was given only a place in the committee on claims and in the committee on expenditures in the war department. In his first session he paid his tribute to party regularity in the debate on remitting the fine levied on General Jackson by Judge Hall of New Orleans and took part in the sectional struggle over the reception of abolition petitions which was now marked by the baiting of John Quiney Adams. Johnson acensed the north of conspiring to break up the union through its attack on the south. "But when we of the 
South," he said, "who represent the interests of the slave states, contend for our rights Gentlemen say 'Oh you are too much excited, too much heated' . . .' He denounced the famous statement of Adams in the last congress, that in case of a servile war the free states if called in to suppress insurrection in the sonth might establish emancipation. ${ }^{52}$ At a later time a friendly editor said ${ }^{53}$ that John Quincy Adams had declared Johnson to be possessed of more native ability than any man in the house of representatives. The literal exactness of this report may well be doubted; but in the memoir of Adams there is found an expression of appreciation for Johnson's support in a matter of parliamentary detail. ${ }^{54}$

While always in line with his party as against the whigs, Jolnson nevertheless appears to have taken every possible opportunity to manifest his independence of the party leaders. Thus it happened that Stephen A. Douglas, Jefferson Davis, and Thomas H. Bayley of Virginia all felt the lash of Johnson's tongue. With these as with many of the whig leaders the occasion of ugly passages of debate was usually some sentiment or allusion which Johnson chose to consider as in some way reflecting upon the workingman. Again and again, sometimes it would seem with deliberate intent to pick a quarrel, or at least with a disposition to choose an unpleasant interpretation of a word, Johnson rose to declare himself the friend of the laborer. It is not hard to understand the bitterness with which such a man as Jefferson Davis, for instance, would remember such encounters, ${ }^{55}$ nor to see that Johnson's manner must have interfered with his success in the larger fields of politics.

Quite as characteristic was the attitude of Johnson towards political matters. He supported all the measures of Polk's administration, but denounced the administration's plan to tax tea and coffee as oppressive of the poor. He conceived a bitter animosity to the new Smithsonian institution, and historical students will doubtless place him in their black books because he opposed

52 Congressional globe, 28 congress, 1 session, 212-214.

53 Nashille Union, May 10, 1853.

54 Mcmoirs of John Quincy Adums, comprising portions of his diary from 1795 to 18.48, edited by Charles Francis Adams (Philadelphia, 1874-1877), 12: 240.

55 Jefferson Davis. Rise and fall of the confederate government (New Tork, 1881), 2: 70.7; Varina B. H. Daris, Jefferson Daris, ex-president of the Confederate States of America; a memoir by his wife (New York, [1890]), 1: $242 \mathrm{ff}$. 
appropriations for the relief of Mrs. Matison in the matter of the purchase of the Madison papers. He pressed with great energy his belief that there was an mufair distribution of the offires at the command of the executiver, ureerl that these should be divided in aceordanee with geographideal renions and maintained that farmers and merhanies slonld be givon a latrer proportion. He proposed that the members of the supreme coult should be put upon the elective basis, supported the fimniliar amendment which looked to changing the alection of thr president, and brought in one of the early amembments for the populatr election of senators. ${ }^{57}$

Notwithstanding his radical prineiples, thongh one can hatrlly suppose it was because of them, Johnson served five terms in the house of representatives. Various competitors canvassod his district against him, of whom the most hitter in personal animosity was William G. Brownlow who poured upon .Johnson all the poli-

56 The exercise of the executive fratrouage and Jolnson's diseontent therewith formed the subjeet of an earnest eonversation between folmson and Presilent Polk. The diary of James K. Polk during his presidency. 1845 to 1849 , ellited ly Milo M. Quaife (Chieago, 1910), 2: $35-41$.

57 Nash cille Cnion, Nay 21, 1S49, eiting "Gallery of portraits of past and present members of congress," No. 1, in New York Sunduy Times, gave an extended sketeh of Andrew Johnson, from which the following laragraph is taken:

"Owing to the want of early advantages, of which I have written ahove, Mr. J. at times slashes his mother-tongue, - pronouneing words of many syllables, or of recent foreign derivation, with little regard to rules laid down by Walker or Wehster. More or less of his fellow-members will titter and sneer at Mr. .l.'s many false anglicisms; get I have rarely seen it done, save by someone smarting nnder the point of his oratorical bowie-knife. Though expressed in uneouth phraseology, his views are easily understood; for he talks strong thoughts and carefully culled facts in quick sucees. sion. Ile thrusts his opponents through and through, as with a rusty and jagged weapon, tearing a big wound and leaving something hehind to fester and he remembered. Woe be unto the luekless wight who offers him a personal inclignity - easts a slur upon him, in dehate; for if he has to wait two years for the opportunity, when it does come, Mr. J. makes the best use of it. IIe puts no hridle upon his tongue; yet he is never guilty of a personal disrespect to a fellow-memher, or even to the opposite party as a whole. Perhaj's I may fairly characterize his efforts as heing slashingly crushing, for he ehops to mince-meat and then grinds to powder the men, measures and principles he may he eontendiug against. The takes and maintains positions at times, which I ean hear no other man arlsoeate without feeling morally sure that the man is speaking without the least regard to the effect of his words upon his own prospects as a public man. IIe is emphatieally the Ledru-Rollin of the House - that is, if Mr. Ledru-Rollin is an honest man. Mr. Jolunson is, however. by no means afficted with socialism. He would be the last man in the IIouse to sanction the robbery of either class in soeiety to jension any other elass - not he." 
tical vitriol of which he had so vast a supply and whom Johnson in return described as a "liyena." This domination of his district by Johnson was overthrown, not by any opponent, but by a gerrymander which the whigs arranged in 1852 with the deliberate intention of depriving Johnson of his seat. His answer to the challenge was to make the race for the governorship. Not only did he succeed but for the first time in a number of years a reelection followed. At the end of his second term he was able to bring to pass his election as senator; two years later he selected the other democratic senator, and in 1860 his name for several ballots was presented as that of a "favorite son" in nomination for the presidency by the Tennessee delegation in the Charleston convention. When one realizes that this political progress was maintained in spite of the opposition secret or open of many of the democratic leaders in the central and western parts of the state one sees all the more clearly the power that Johnson exerted over the mass of the voters in the state as a whole.

The congressional contest in which Brownlow sought to defeat Johnson was that of 1845 . In answer to the attacks of Brownlow Johnson pursued the very customary course of issuing an address to his constituents. This was full of bitter controversial matter which, beyond one statement, is of no significance here. He attacked one of the community who, he said, "is violently opposed to me no doubt because I am too much the poor man's friend; because I, while a member of the Twenty-eighth Congress, was in favor of giving to every man, who could not raise a sum of money sufficient to pay the government price for the public land, a certain number of acres, (the numbers of acres though to be regulated in proportion to the number of children in family, free of charge, by his moving to and settling upon it. While I have been standing by the poor man in getting him a lome that he could call his, it will not be out of place, in this connexion, to ascertain what the opinions are of those who have been trying to crush me in the estimation of the people." 58

The paternity of great public measures is often as much disputed as Homer's birthplace; and the parentage of the homestead bill has been claimed for many persons. ${ }^{59}$ In a very schol-

58 Letter of Andrew Johnson to his constituents.

59 This has been due in lart to a failure to distinguish carefully the homestead principle from that of the "log cabin" bill. 
arly dissertation the latest writer mon this poriod in the history of the public lands, Mr. George M. Stephenson, hats duly noted the resolution introduced fannary 4, 1844 , in the cours.s. of the first session of the twenty-eighth eomgress, which was to instruct the committee on publie lanels to induire into the expediency of passing a law to donate cighty aredes of land to rexply actual settler "being the head of" a family and living with the same and not now the owner of land and who thromgh misfortune or otherwise is mable to purchase." This resolution wats submitted by Robert Smith of Illinois. But Mr. Strphenson does not call attention to the fact that these lands were to be selected from those which had been ten years on the narket,

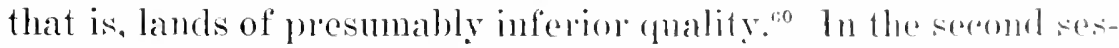
sion of this congress an amendment to the graduation bill, proposed by Thomasson of Kentucky, undertook to donate to every actual settler "being the head of a family" forty acres. It appears from the debate that this, too, had reference to lands that had previonsly been offered for sale. ${ }^{61}$ In the first session of the twenty-ninth congress, however, independent homestead bills were introduced by Felix Grundy McConnell of Alabama and by Andrew Johnson of Temnessee. ${ }^{62}$ It was at this session, as we have made clear above, that the graduation and reduction bill came so near passing; and both the bill of MeComnell and that of Johnson, ${ }^{63}$ together with the two carlier propositions

60 Stephenson, Political history of the public lands, from 1840 to 1862 , from preemption to homestcad, 116; Congressional globe, 28 rongress, 1 session. 10.. In the following session, when the graduation bill was dohated at length, Smith, on December 27, 1844, made a speech in reply to Causin of Maryland, who hal upheld the eastern point of view. Ilid., 28 eongress, 2 session, $69 \mathrm{ff}$. In the first session of the next congress, on July 9, 1846, he male another extendel speceh on graluation, in which he referred to his resolution introluced in 1844. Ibid., ag congress, 1 session, $1062 \mathrm{ff}$.

61 Ibid., 28 eongress, 2 session, 241. Cf. J. B. Samborn, "Some politienl aspeets of homestead legislation,' in American historical rericw, 6: 27.

62 MeConnell asked permission to introduce his hill January 9, 1S.16. Congres. sional globe, 29 congress, 1 session, 172. Johnson asked another memler to waive a motion which he wished to offer, to allow him (Johnson) to introdnee his hill, but failed (March 9). Ibid., 472. On March 12 he asked leave of the house to introduee the bill. Ibid., 492. On March 27 he introduced the bill. Ibid., 56.8. A cop! of this bill (H. R. No. 319) was kept by Andrew dolnson and is still with a number of printed homestead bills in the .Johnson lajers, library of congress.

63 On December 11, 1845, Ficklin of Illiuois also submitted a bill to grant lands to aetual settlers "under eertain limitations." Congressional globe, 29 eongress, 1 session, 43. The eontent of the bill does not appear. 
mentioned, were closely connected with the parliamentary course of that measure and illustrated what we have called the western point of view. Illinois, Kentucky, Tennessee, and Alabama pretty well represent that section of the country. ${ }^{64}$ But among the petitions of 1844-1845 is one presented by Severance of Maine from Dudly P. Bailey and forty others of the same state requesting that congress "should pass with all convenient haste, a law by which every citizen, who may be desirous of cultivating the earth for a living, shall be enabled to enter upon the public lands and occupy a reasonable sized farm thereon free of cost." ${ }_{65}$ A similar petition from Alleghany county, Pennsylrania, was presented Jannary 30, 1846, by Darragh of that state ${ }^{66}$ and a few days later Herrick of New York presented a memorial of the National Reform association with regard to the public land which was referred but not printed. ${ }^{67}$ Herein are seen early manifestations of the radical eastern propaganda. ${ }^{68}$

McConnell, who seems to have been regarded by the house as something of a wit and to have been taken not very seriously, tried several times early in the session to introduce his bill which was to provide a home for "every man, maid or widow being the head of a family." "69 The last time he used the word "lhomestead:" "70 but this does not seem to have been in general use at this time. Andrew Johnson, many years later, claimed that his introduction of the bill antedated that of McComnell, ${ }^{71}$ but it appears that McConnell really made the first efforts. ${ }^{72}$ Both

64 Thomasson, homever, expressed a desire to remove the lanis from the national treasury because he dil not wish revenue from the public domain to break down the tariff.

65 January 3, 1845. Ilid., 28 congress, 2 session, 89.

66 Ibid., 29 congress, 1 session, 283.

67 March 9, $1846 . \quad$ Ibid., 471.

68 The plans of Johnson and MeConnell both fell short of the denands of the land reformers. Documentary history of American industrial society (Commons and associates ed.), 8: 64-65.

69 Congressional globe, 29 congress, 1 session, 172 (January 9), 420 (February 24), 473 (Mareh 9), 558 (Mareh 26), 1045 (July 1).

70 Ibid., 1063 (July 6).

71 Ibid., 35 congress, 1 session, 3043 .

i2 It was the advice to his students of a great teacher of history, Herbert $B$. Adams, to "avoid the use of the superlative." This applies, in general, to the efforts of historical writers to locate the "first", appearance of an idea; and, in particular, to the anthorship or "fatherhood" of the homestead bill. Ten years before the period under consileration a Mississippi representative in congress, Franklin E. 
Johmson and MaCommed tried also to talek their malsures on to

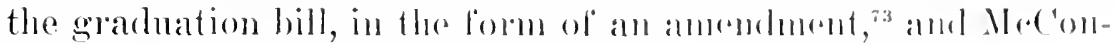
nell made similar elforts in ammertion with other hills.

Within a few months Meremell ammitted suicide. Johnsont rontinued in eongress and therefore had the advantange of making repeated offorts to seculre ansidaration for his bill.

The suggestions of giving arants of land to settlers which in the forms of petitions, resolutions, separate bills or amendments to the graduation and reduction hill had in $184+1846$ usherest in the beginnings of the homestead discussion were not followed up decisively in the congress of 1847-1849. The political maladjustment cansed by the election of a whig house of representatives, the agitation over the Wilmot proviso, the biekering over the conduct of the Mexiean war and the influenee of the bounty law all acted mnfarorably. But the agitation of the eastern radicals was having its effect. Tn the presindential cantpaign of 1848 the lant reformers triecl to enlist Martin Tan Buren in their cause; bnt that wily politician and even the framers of the Buffalo platform were afrail to come ont clearly for the full program of Evans and his followers. The Buffalo platform did include a homestead plank. Van Buren, however, declared himself not ready to assent to the free gift of the puhlie lands. On the other hand Greeley gave his support to General Taylor and the regular whig ticket. Thus the adherents of land

Plummer, a native of Massachusetts, presented a jetition of sumlry citizens of Mississippi and made a specel thereon. The petition prayed for a law granting to each native citizen of the United States not alrearly a landholiler and who was not worth five hunelred dollars, 160 acres of land on condition of settlement and eontinued eultivation for the period of five years. In his speech upon the petition Plummer sail the condition of white men too poor to jurchase a lome was worse than that of the Indians. The petitioners were thankful for the jrëimption laws, but askel for donations. They pointed out that the Mexiean republic was holling out actual donations of land to settlers and that many would be compelled to seek in a distant land a home which they cond not obtain here. Plummer confemmed the United States government as the only nation on earth that ever arloptel a poliey of holding up its waste and unappropriated lands as a souree of reveme exeept for some temporary reason. This may stand as the "first" congressional proposal of a real homestead measure, - until someone diseovers an earlier one. Reyister of debates in congress. 1834-1S35, 11: part 2, 1566-1570.

73 Congressional globe, 29 congress, 1 session, 1077 (.Johnson, July 10) ; 1192 (MeConnell, August 4); 1200 (MeConnell, August 6, on the Oregon bill). The hill of Johnson is reprinter in Documentary history of Ameriean industrial society (Com. mons and associates, ed.), 8: 62-64. 
reform were divided. ${ }^{7}$ Though in the east the homestead idea found friends in several political groups, no effective political organization made the measure exclusively its own. Thus in this period the history of the homestead bill had for the time a nompartisan aspect different from that of the graduation bill in the campaign of four years before.

After the election the homestead principle again appeared in the house in two bills differing in content, the one submitted by Andrew Johnson, the other by Horace Greeley, a member of this congress. During this short session Johnson through illness was unable to look after his bill; and so he placed it in the care of his Tennessee colleague George W. Jones. ${ }^{75}$ Jones accomplished nothing, and Greeley's bill was speedily tabled. ${ }^{76}$ Greeley left congress, but Johnson had taken a fresh start and at every session during the remainder of his membership in the house of representatives he introduced a homestead bill in one form or another. In the thirty-first congress, that of the compromise of 1850 , he had played a part of some importance in the election of Cohb as speaker, and for the first time was given the chairmanslip of a committee, - that on public expenditures. ${ }^{77}$ When lie found the committee on public lands predisposed in favor of its own measure of graduating and reducing the price of the public lands, he tried the umusual expedient of reporting his bill from the committee on public expenditures, - his own committee. This naturally aroused instant protest. It was insisted that such a bill should go to the committee on public lands. ${ }^{78} \mathrm{He}$

7. See note 46 above, and Stejhenson, Political history of the public lands, from 1840 to 1862, from pre-cmption to homestead, 135-139. Theodore C. Smith, in his The liberty and free soil partics in the northuest (New York, 1897), discusses the election of 1848 , but has little to say of the relation thereto of the question of the public lands.

75 Johnson gave notice of his bill December 11, 1848. Congressional globe, 30 congress, 2 session, 25. Jones tried to introduce the bill February 14, 16, 1849. Ibid., 534,548 .

76 'The bill was tabled by a viva voce vote February 27, 1849. Ibid., 605. There was also a bill presented by E. Embree of Indiana, February 5, 1849. Ibid., 454.

77 Ibid., 31 congress, 1 session, S8. Two years later he resigned this post, on the ground that he had nothing to do.

is He gave notice Jamuary 7, 1850. Ibid., 131. On February 25 he reported the bill from his own committee. Ibid., 40s. Securing unanimous consent he introduced his bill February 27, and asked that it be referred to the committee on agrienlture. This was refused and the bill was referred to the committee on public lands. Ilid., $423,424$. 
then tried a new tack. Finding more fricmlly sone of the rommittee on algrientuture, he ehamged the titte of his bill so that it

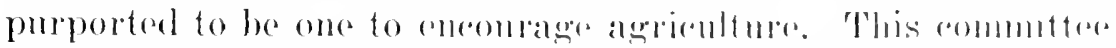

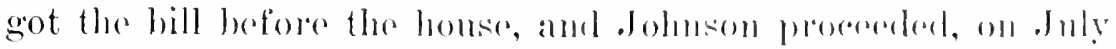

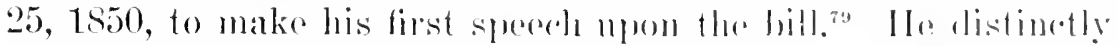
stated that this hill was a homestoud hill, and remarkond that

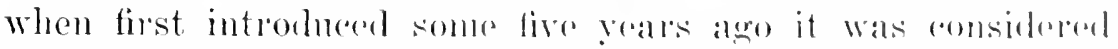

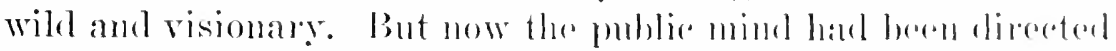
towarl the measme and the most prominent men of the romentry were vying with each other in smport of it. Somators "possessing the tallest intellect" had entered the competition. Ho. wished it to be distind y understood that he was "no atgrarian, no leveller, as they were tormed in modern times." lle wisher] to elevate, not to pull down. In support of his proposition he cited Moses, Vattel, and Andrew .Jackson, a somewhat ("llrions combination of anthorities. When he arened that the domain of United States belongerl to the people as a whole, as much ats the other great elements, air, fire, water, he was coming pretty close to the ideas of the land reformers.

Johnson's bill did not come to a vote. ${ }^{80}$ But that a change was developing in the estimate which the public mind placerl on this measure was manifested in the presentation in the semate of various propositions by Seward, Donglas, Wobstor and Sam IJouston, ${ }^{81}$ while Walker of Wisconsin snggesterl a combination of a homestead plan with one of ession to the states. ${ }^{82}$ Sewarl's resolution looked to a grant of land to the exiles from linmerery; and it was over this phase of the question that most of the debate took place.

In the short session of 1850-1851 Johnson again introduced

i9 He gave notice of the new lill Mareh 4 , and June 4 it was introdueed and referred. Ibid., 448, 1122. The committee on agriculture reported the lill and lohnson spoke on July 25. His speed is griven at length in ibid., alpremlix, 2: 9.50-9.5.

80 A bill proposed hy Moore of Pemscrlvania "to discourage speculation in the public lanils", was also a homestead lill. Ibid., 139, 4't.

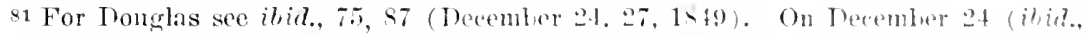
75) Cass had introduced a resolution looking to the severance of diplomatic relations with Austria. Seward's resolution to grant land from the pullie domain for the Eungarian exiles was offered Jantary 9, 1950. Ilid., 128. On .lannary ㅁ․, Webste? moved his resolutions which on March 28 , on his orm motion, were postioned. Ibid., 616. Houston's proposal was name lanuary 90. Ibid., 269.

82 December 24,1849 . Ibid., 74 . 
his bill, ${ }^{83}$ as did Walker in the senate. This time Johnson was supported by George W. Julian, who acknowledged ${ }^{84}$ his debt to Jolmson for the opportunity of making a speecli. But future dangers in the way of the bill were made evident when Julian combined with his advocacy of the homestead bill an out and out abolition argument very unflattering to the sonth. ${ }^{85}$

The first session of the next congress, the thirty-second, immediately preceded the presidential canvass of 1852. A homestead bill finally passed in the house of representatives, notwithstanding the rivalry of a new form of distribution proposed by Bennett and very favorably received, and also an amendment skilfully urged by Cobb of Alabama, who professed friendship to the homestead principle. There was a long and interesting debate, ${ }^{86}$ which revealed the importance which the bill had now attained. Early in April Johnson wrote to his friend Patterson "The 'Homestead' will pass without doubt mless some influence is brought to bear against is not now seen or known to exist. Various M.C. who were considered against it during the last Congress are now for it, viz. Toombs, Stephens, Venable, etc. The mongers in land warrants are opperating $[$ sic $]$ to some extent against it. I think in the end that can be turned to good account." ${ }_{87}$

In comnection with the work of this session we have the most complete evidence of the relations that existed between Johnson and the land reformers of New York who, through the assistance of Greeley, were insistent in their pressure upon congress. Shortly after the bill had passed the house of representatives

83 This session was marked by a considerable persistence on Jolmson's part, and by evidences of opposition to the introduction of the bill on the part of those who controlled the honse. Ibid., 31 congress, 2 session, 22, 76, 94, 204, 216, 365, 752.

84 George W. Julian, Political reeollections, 1840 to $187 \mathscr{8}$ (Chicago, 1884), 103-104.

85 January 29, 1851. Congressional globe, 31 congress, 2 session, appendix, 135.

si 'The bill passed the house May 12, 1552. Ibid., 32 congress, 1 session, 1348 ff. The course of the dehate on the bill may be traced by the indexes to the Congressional globe and appentix. Well chosen selections are printed in Documentary history of American industrial society (Commons and associates ed.), 8: 65-78. Among the members of this house who took up the cause of the homestead bill was Galusha A. Grow of Pennsylvania, then serving his first term. Grow was the youngest memler of this congress. His hiographers point out the fact that he became a disciple of Thomas Hart Benton, then a member of the house. James T. DuBois and Gertrule S. Mathews, Galusha A. Crow, father of the homestcad law (Boston, 1917).

\&z Andrew Johuson to D. T. Patterson, April 4, 1852. Johnson papers, library of congress. 


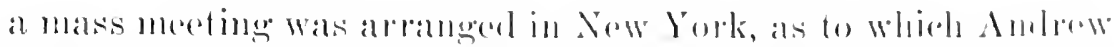

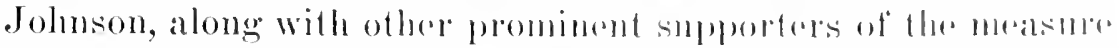

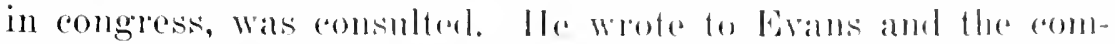
mittee on invitation on May žt in high apporal of the montime, but characteristically urged "I hope your will have your merting

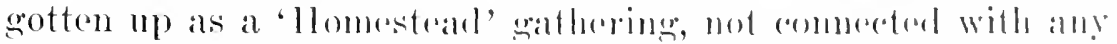

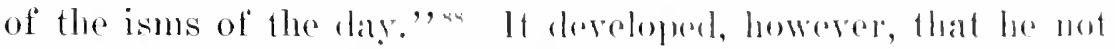
merely wrote a sympathetic letter, hut attomber the meetimg ambl made the principal sperech. Ireoreling to plan the amblemere sathered in the park on the afternoon of May 27 , hut was soon driven by a rainstom to lake refuge in the rotmela of the aity" hall. The crowd of hearers was describer hy the Tribune as lare and enthusiastic; (ireeley save an extonsive smmmary of Johnson's speceh, and editorially praised it in troms that worr warm and sincere. ${ }^{89}$ Several weeks later. Johnson wrote 10 a friend "I was in Now York some time since. . . . I harl quite a pleasant time of it in the Empire City, was trated three with marked kindness and attention.",90

But the senate was deaf to outside appeals and ifused to pass the bill. ${ }^{91}$ Though he came from a western stats. and thomgh the west was now becoming nearly manimous for the 'omestear, Felch, of Michigan, chairman of the senate committee os! public lands, was unfriendly and found support in a special (e)mmmmication from John Wilson, the commissioner of the ereneral land office. This included a critivism of the pluraseology of the hill as submitted to him, and suggestions for improvement in this

ss New Fork Daily Tribune, May 28, 1852. In the course of Andrew Johnson's canvas for reälection to the governorship of Tennessee, in 1555, his afliliation with the "land reformers", was bronght up against him by his political opponents as proof of his disorganizing and revolutionary doctrines. It was eharged that his first message as governor had been eopied from the "Address to the voters of the United States" put forth ly the industrial congress of 19.52 , and his presene at the later sessions of the eongress and his association with Gerrit Smith, Seward, Chase, Sumner and I. P. Walker of Wisconsin was used in the attempt to discrelit him at home. Republican Bamner and Nashille Whig, .luly 14, 1955. At the session of the industrial congress held in Allany, New York, at whieh I. P. Walker was nominated for the presileney, Johnson received three votes for that nomination on the first ballot, and his friend A. O. P. Nielolson, who had expressed very liberal views on the land question, received two rotes. New York Maily Tribune, Iune 9. 1451.

so New York Daily Tribune, Niy $28,195 \%$.

90 Andrew Johnson to S. Milligan, July 20, 1852, naunseript in Pennṣvania historical society.

91 Congressional globe, :22 congress, 1 session, 135:, 1521, 2100, 2066. 
respect, and also an opinion as to the merits of the measure as a whole, which was very unfavorable and brought up all the standard objections, - that the bill would involve a great loss of revenue, that this would involve a higher tariff or direct taxation, that the public lands were pledged by congress for the payment of the public debt, that the contracts with the states made upon their admission to the union would be impaired, that there was no discrimination as to the lands open to selection, so that mineral lands would be included, that no great national object was proposed, that the country would be deprived of this vast resource in the case of futmre wars, and that congress would draw on themselves an influence as irresistible as the force of gravitation. $^{92}$ These criticisms suggest other phases of the history of the public lands very closely interwoven with the political fortumes of the homestead bill, into the detailed consideration of which, in this paper, it has been impossible to enter. ${ }^{93}$ The appropriation of vast quantities of land by the several bounty laws has been noticed; the extensive grants to railroads were already begun; California and the new territories presented their peculiar problems; it had been proposed to make gifts to hospitals for the indigent insane. Even more dangerous to the peaceful progress of the homestead bill was the sectional animosity threatened when Mason of Virginia identified the agitation for the homestead with the candidacy of John P. Hale for the presidency ${ }^{94}$ The increasing devotion to the measure of those who were attacking the institutions of the south was sure to turn sonthern support to southern hostility. Greeley claimed, however, that in the house more sonthern members voted for the bill than against it $:^{95}$ and in his New York speech Johnson

92 John Wilson, acting commissioner, to A. Feleh, June 18, 1852. House of repre. sentatives papers, library of congress.

93 For the political history of these years see Stephenson, Political history of the publie lands, from 1840 to 1862, from pre-emption to homestcad, ehs. 10, 11; and for a less dependable account, Dubois and Matthews, Galusha A. Grow, father of the homestead lau, ch. 4. Cf. also John B. Sanborn, Congressional grants of land in aid of railuays (Madison, 1899), and "Some political aspects of homestead legislation," in American historical review, 6:19 ff.; L. H. Haney, A congressional history of railways in the United States to 1850 (Madison, 1908), and $A$ congressional history of railways in the United States, 1850-1887 (Nadison, 1910) ; Benjamin W. Palmer, Suamp land drainage with speeial refcrence to Minnesota (University of Minnesota Bulletin--Minneapolis, 1915); Orfield, Federal land grants to the states with special reference to Minnesota.

9. Congressional globe, 32 congress, 1 session, 2267.

${ }^{55}$ New Tork Daily Tribune, May $28,1852$. 
hat eloquently pleaded the nompartisan chatrater of the meatsure.

The victory of Pieree, while favorable to the snceress of the graduation and reduction bill, was not esmeouraging for the homestearl. In the short session that preereded the inauguration of Pierce the bill was again introdneerl in both houses, but again the result was failure.96 At the resese of this session, as has already been said, Antrew Johnson left the house of representatives to serve four years as governor of 'Temmessee and then to return as senator to the congress of the Uniterl States.

Coincisling in point of time with the beginning of the Piores administration, the withdrawal of Johnson from the house drefines a period in the history of the hill as well as in that of his own career. Reviewing what has been nilluated we find that the homestear bill had its origin in a combination of forces. On the one hand it was an off shoot of the demand of the settler of the west for a further modification of the land systrm, and devoloped out of the proposal for graduating and reducing the price of the public lands. This policy of graduation was western, even southwestern, in its souree, and politically was comnecterl with the régime of Jacksonian democracy. But the homestead idea differed from the Bentonian scheme; and the diflerence consisted in the very elements which were embodied in the radical agrarianism of the eastern labor moveraent. With reference to the work of Erans Mr. Commons has written: "Not for" the sake of those who mored west dirl Evans adrocate freplom of the public lands, but for the sake of those who remainul cast. This was the idea that he added to the idea of Andrew .Jackson and Andrew Johnson." ${ }_{97}$ This identification of the attiturle of Jackson and the attitude of Johnson seems to be mistaken. Johnson, who represented a southwestern state, was possessed of ideas very similar to those of the land reformers, if not derived therefrom, and it is just this fact that makes distinctive his contribution. Originally opposed even to the further redue-

96 The later phases of the bill to 1862 are discussed by Sauborn. Congressimal grants of land in aid of railuays; by DuBois and Mathens, Galushe A. Groul, father of the homestead law (with some exaggeration of the part linyed hy (row); and by Stephenson, Political history of the public lands, from 1840 to 1562. from pre-emption to homestead, chs. 12-15.

97 Doeumentary history of American industrial socirty (Commons and associates ed.), 7 : introduction, 31 . 
tion of the price of the public lands, opinion in the east was converted to the abandomment of the revenue policy for that of free grants. The earlier phases of the homestead movement brought to pass this change and the fusion of the eastern and the western points of view. In the accomplishment of this Andrew Johnson, of East Temnessee, played an important part. Not the inventor of the homestead idea, which can hardly be said to have been invented at all, and probably not the first to introduce the proposed legislation in congress, he was the first practical politician to make this policy particularly his own and persistently to force it upon the attention of congress.

In 1850 Johmson had written to his son-in-law: "I have strong hopes of getting the homestead bill through this winter. If I do I shall die happy." "98 He had now found reinforcement in the east, to whose artisan classes his personal appeal miglit one day be powerful. He could count certainly on some support from the south and southwest. The northwest was of all sections the one most certain to approve of the homestead bill. It must have been with some bitterness, therefore, that he left the honse of representatives with his work yet uncompleted. But if it seemed hard to leave to other's to reap the field where he had borne the burden and heat of the day, Johnson had at least brought it to pass that he himself was recognized as responsible for the success which thus far had been accomplished. On February 24, 1853, Senator Dodge of Iowa, replying to Senators Charlton and Dawson of Georgia who had opposed the homestead bill of this session, gave an historical retrospect concerning the bill in which he appealed particularly to the southern origin both of the principles of the bill and of the emigrants who profited by it. He quoted Macon of North Carolina, pointed out the support given by men of that type in North Carolina and Virginia to Benton's graduation bill which had passed the senate more than twenty-five years before with a provision for donating the refuse lands to actual cultivators. "After a seven years' struggle of the people's representatives in the other honse" the homestead bill "thus assailed in advance in this body, passed. And I now have in my eye its indefatigable and

98 Andrew Johnson to D. T. Patterson, December 23, 1850. Johnson papers, library of congress. 
indomitable author, an esteemed friend and member of the House, (Hon. Andrew Johnson of 'T'ennessees,) to whom, as one deeply sympathizing with him in sentiment, I retnrn my thanks as an Iowa man. He is the type of the men for whom this bill is intended-now a most able and faithful member of Congress, once a mechanie struggling with poverty and working with the hands which God gave him, and expending that sweat by which it was the decree of the Amighty that min should obtain his bread." ${ }_{99}$

As the career of Andrew Johnson peculiarly illustrates the opportunity which democraey in this country has offered, so the evolution of our land system, though accompanied by much that has been eostly and wasteful, has yet been an evidence of the workings of self government. In the past the influcine of the frontier, with its opportunity for the easy accuisition of lanm, has been potent as a factor distinguishing American conditions from those in the old world. Now, the era of free land has abont ended, and there is no longer the vast domain of unbroken prairie that was open for the operation of the homestead law. But it is hardly to be doubted that the land problem will remain, appearing in new phases, the solution of which will tax the best efforts of those who will derote themselves to the great reconstruction that must follow the present war; in which, as in the successful conchusion of military effort, the United States will, we know, play a part wortlyy of its vast power.

St. George I. Sioussit.

Brown University

Providence, Rhode Island

${ }^{99}$ Congressional globe, 32 congress, 2 session, appendix, 202. 

tin 
LIBKAKY OF CUNGKESS

(1) | (1)

$0 \quad 002 \quad 0245864$ 


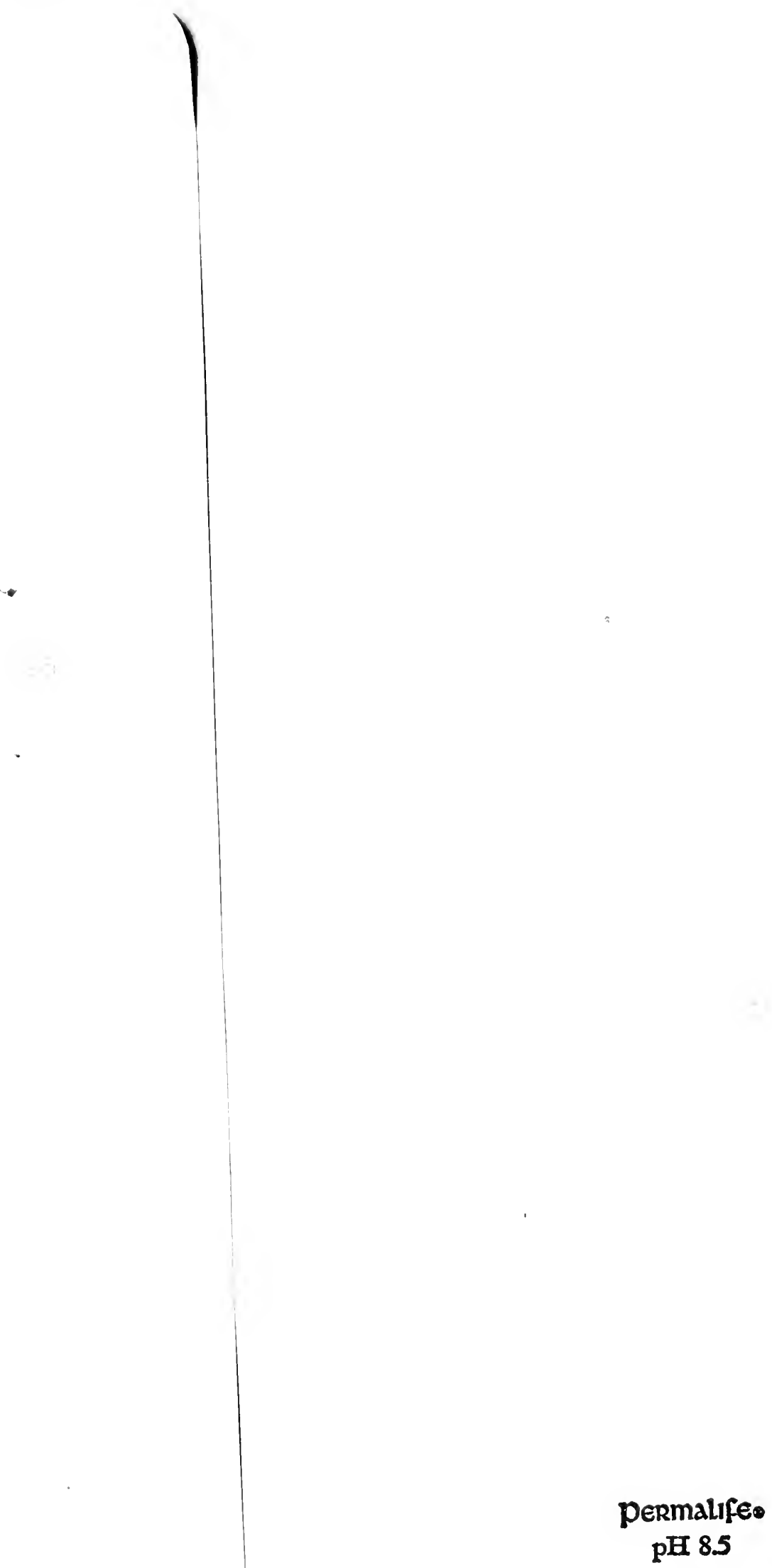

